\title{
REKONSTRUKSI PENCABUTAN HAK ATAS TANAH DAN KONSINYASI DALAM PENGADAAN TANAH UNTUK KEPENTINGAN UMUM ${ }^{1}$
}

\author{
Iwan Erar Joesoef \\ Universitas Pembangunan Nasional Veteran Jakarta \\ Jl. Fatmawati Raya Nomor 1, Pondok Labu, Jakarta \\ iwan.erar@upnvj.ac.id
}

\begin{abstract}
This study aims to examine the use of the concept of revocation of land rights and compensation with custody in court (consignment). The scope of the research is land acquisition for public interest in toll road infrastructure development in Indonesia. In the law on land acquisition for public interest it does not explicitly mention the revocation of land rights, but the application of the concept of compensation for land acquisition for public interests deposited in court results in the loss of land rights and land falls to the state. The research method is normative juridical. The results of the study show that the revocation of land rights and the urgency of the consignment is more appropriate to be applied to the development of public infrastructure by the government. Meanwhile, the development of public infrastructure by the private sector in the governmentprivate partnership model is unfair to implement because it is commercial in nature.
\end{abstract}

Keywords: Revocation of Land Rights; Consignment; Land Acquisition; Public Interest.

\begin{abstract}
Abstrak
Penelitian ini bertujuan mengkaji penggunaan konsep pencabutan hak atas tanah dan ganti rugi dengan penitipan di pengadilan (konsinyasi). Ruang lingkup penelitian adalah pengadaan tanah untuk kepentingan umum dalam pembangunan insfrastruktur jalan tol di Indonesia. Dalam undang-undang pengadaan tanah untuk kepentingan umum secara eksplisit tidak menyebut pencabutan hak atas tanah, namun penerapan konsep ganti rugi pengadaan tanah untuk kepentingan umum yang dititipkan di pengadilan berakibat hilangnya hak atas tanah dan tanah jatuh kepada negara. Metode penelitian yang digunakan adalah yuridis normatif. Hasil penelitian bahwa, pencabutan hak atas tanah dan konsinyasi urgensinya lebih tepat diterapkan pada pembangunan infrastruktur publik oleh pemerintah. Hal ini sesuai dengan Pasal 33 (3) UUD NRI Tahun 1945. Sedangkan pembangunan infrastruktur publik oleh swasta dalam model kerjasama pemerintah swasta tidak adil untuk diterapkan karena bersifat komersial.
\end{abstract}

Kata Kunci: Pencabutan Hak Atas Tanah; Konsinyasi; Pengadaan Tanah; Kepentingan Umum.

\footnotetext{
${ }^{1}$ Artikel hasil penelitian mandiri yang dilakukan penulis pada tahun 2020.
} 


\section{A. Pendahuluan}

Dalam sektor infrastruktur, pengadaan tanah untuk kepentingan umum sangat penting untuk diperhatikan. Masalahnya adalah pengadaan tanah tersebut banyak menimbulkan sengketa pertanahan antara Pemerintah, Penyelenggara Infrastruktur (Pemerintah, Badan Usaha Pemerintah dan Swasta dalam bentuk Kerjasama Pemerintah Swasta) dan masyarakat pemilik tanah. Permasalahan yang timbul umumnya terkait jumlah ganti rugi atas pembebasan tanah untuk kepentingan umum(Kasenda, 2017). Salah satu contoh dalam penelitian ini adalah pengadaan tanah untuk pembangunan jalan tol. Proses memenuhi target politik untuk membangun jalan tol sepanjang sekitar $1.600 \mathrm{Km}$ yang tidak terpenuhi, yang salah faktornya adalah karena hambatan pengadaan tanah telah memberikan pelajaran yang sangat berharga bagi pembangunan jalan tol ke depan (Toll Road Regulator (Badan Pengatur Jalan Tol), n.d.).

Hambatan pengadaan tanah tersebut pada tahun 1997 Menteri Keuangan mengeluarkan Surat Edaran yang membebankan biaya pengadaan tanah kepada pihak swasta. Akibatnya pembangunan jalan tol oleh investor swasta menjadi terhambat dalam periode 19972004. Lihat Disertasi Iwan Erar Joesoef, "Model Kerjasama Pemerintah dan Swasta: Studi Penerapan Kontrak Build Operate Transfer dalam Perjanjian Pengusahaan Jalan Tol di Indonesia", Program Pascasarjana, FHUI, 2011 (Joesoef, 2011). Dengan demikian pelaksanaan pengadaan tanah untuk kepentingan umum harus memberikan kepastian hukum dalam regulasinya juga memberikan keadilan bagi masyarakat atas kepemilikan tanahnya.

Undang-undang pengadaan tanah untuk kepentingan umum secara eksplisit tidak menyebutkan Undang-undang Pencabutan Hak Atas Tanah namun menggunakan terminologi penitipan ganti rugi dan pelepasan hak di pengadilan (konsinyasi). Pada saat konsinyasi tersebut maka hak kepemilikan tanah mayarakat yang berhak tersebut menjadi hapus dan alat bukti haknya menjadi tidak berlaku serta tanahnya menjadi tanah yang dikuasai negara. Undang-undang Pengadaan Tanah untuk Kepentingan Umum juga tidak membedakan badan yang memerlukan tanah apakah itu Pemerintah, Badan Usaha Milik Negara atau Swasta dalam bentuk Kerjasama Pemerintah Swasta (Undang-undang Pengadaan Tanah untuk Kepentingan Umum, 2012)

Jika dilihat dari status pihak yang memerlukan tanah, maka konsep pencabutan hak atas tanah dan konsinyasi sangat terkait dengan kewenangan pihak yang akan mencabut hak atas tanah apakah untuk pembangunan infrastruktur publik sesuai amanah konstitusi UUD NRI Tahun 1945 atau pembangunan infrastruktur publik yang bersifat komersial. Disisi lain pihak yang memerlukan tanah dalam undang-undang pengadaan tanah untuk kepentingan umum adalah Pemerintah baik pusat maupun daerah, Badan Usaha Milik Pemerintah baik dalam bentuk perusahaan umum (perum) atau persero, atau Swasta dalam Kerjasama Pemerintah dan Swasta. Jadi undang-undang pengadaan tanah untuk kepentingan umum tidak melihat suatu pembangunan apakah merupakan pembangunan infrastruktur publik dalam arti non komersial atau pembanguan infrastruktur publik yang bersifat komersial. Seperti halnya pembangunan sarana jalan umum dan sarana jalan tol yang berbayar.

Penelitian yang dilakukan Ade Arif Firmansyah, melihat adanya konfigurasi kepentingan antara Pemerintah, Swasta, Masyarakat dan pemilik tanah sebagai pihak-pihak yang berkepentingan dalam pengadaan tanah. Konfigurasi kepentingan tidak seimbang, yaitu pada saat masyarakat sebagai pemilik tanah dihadapkan dengan pemerintah sebagai inisiator pembangunan, swasta sebagai investor pembanguan. Disisi lain masyarakat secara pasif turut memiliki kepenting sebagai pihak yang menikmati hasil pembangunan (Ade, 2018). Jadi terjadi ketidak seimbangan kepentingan dari pihakpihak yang terlibat dalam pengadaan tanah untuk kepentingan umum. Ketidak seimbangan ini dapat dilihat dari pelaku 
pembangunan sarana infrastruktur apakah pemerintah yang non komersial karena amanah Pasal 33 (3) UUD NRI Tahun 1945 atau swasta dalam model kerjasama pemerintah dan swasta yang bersifat komersial.

Dalam penelitian tersebut disebutkan bahwa dalam proses pelepasan hak atas tanah dan pencabutan hak atas tanah (Undang-Undang No. 20 Tahun 1961 tentang Pencabutan Hak Atas Tanah dan Benda-Benda yang Berada di Atasnya, 1961), pemerintah menggunakan hukum publik. Penggunaan hukum publik ini memberikan dampak pada masyarakat pemilik tanah. Salah satu dampak adalah dalam hal perlindungan hukum bagi pemilik tanah. Penelitian yang dilakukan oleh MY Pratama juga terkait kajian atas prosedur dan pengaturan pencabutan hak atas tanah dan benda-benda yang berada di atasnya (Pratama, 2019). Kekurangan dari penelitian ini adalah hanya membahas aspek prosedural dan perlindungan hukum bagi pemilik tanah. Penelitian ini tidak membahas latar belakang, pihak yang memerlukan tanah serta maksud dan tujuan pencabutan hak atas tanah. Sehingga hal ini penggunaan hukum publik oleh pemerintah dalam pengadaan tanah untuk kepentingan umum, tidak melihat dinamika perkembangan pembanguan infratruktur yang sudah bergeser adanya keterlibatan pihak swasta dalam membantu pemerintah dengan pola kerjasama pemerintah swasta.

Penulisan ini bermaksud untuk melengkapi kekurangan dari penelitian tersebut diatas. Dalam penulisan ini, akan dilakukan penelitian terhadap pihak yang berkepentingan dalam pengadaan tanah untuk kepentingan umum. Artinya konsep pencabutan hak atas tanah dan konsep penitipan ganti rugi dan pelepasan hak di pengadilan (konsinyasi) tidak bisa diterapkan pada semua pihak yang berkepentingan atas pengadaan tanah. Dalam pengadaan tanah untuk kepentingan umum disebutkan pihak tersebut adalah pemerintah baik pusat maupun daerah, badan usaha milik negara yang dalam hal ini ada yang berbentuk perusahaan umum (perum) dan persero, serta Swasta dalam bentuk kerjasama pemerintah dan swasta. Dengan demikian dalam perkembangan masyarakat dewasa ini, ada pergerseran paradigma kepentingan umum dengan keterlibatan swasta yang bersifat komersial. Seperti contohnya adalah pembangunan infratruktur jalan tol atau jembatan tol.

Pihak-pihak tersebut di atas berdampak pada tujuan hakiki dari pengertian untuk kepentingan umum, sebagaimana disebutkan dalam Pasal 1 Undang-undang Pencabutan Hak Atas Tanah, yaitu termasuk kepentingan Bangsa dan Negara serta kepentingan Bersama dari rakyat, kepentingan pembangunan yang dalam keadaan yang memaksa. Tujuan penelitian ini adalah untuk membedakan penggunaan konsep pencabutan hak atas tanah dan konsinyasi dalam undang-undang pengadaan tanah untuk kepentingan umum. Pembedaan tersebut adalah dilihat dari pihak-pihak yang berkepentingan atas pengadaan tanah untuk kepentingan umum tersebut. Dilihat dari aspek sejarah undang-undang pencabutan hak atas tanah tersebut adalah dalam konteks kewenangan pemerintah baik pusat maupun daerah dalam melaksanakan amanah Pasal 33 (3) UUD NRI Tahun 1945 yaitu membangun sarana dan prasarana untuk kepentingan umum untuk sebesar-besar kemakmuran rakyat. Sejarah undang-undang pencabutan hak atas tanah tersebut mengacu pada Undang-undang Nomor 20 Tahun 1961 tentang Pencabutan Hak-Hak atas Tanah dan Benda-Benda yang ada di atasnya.

Penelitian ini akan menguji tingkat urgensi dari kepentingan umum sebagai kepentingan Bangsa dan Negara serta kepentingan bersama dari rakyat, kepentingan pembangunan yang dalam keadaan yang memaksa. Pengujian terkait dengan pencabutan hak atas tanah dan penitipan ganti rugi dan pelepasan hak di pengadilan (konsinyasi). Urgensi tersebut dalam hipotesa ini adalah berbeda dari pihak-pihak yang berkepentingan dalam pengadaan tanah untuk kepentingan umum. Pihak pemerintah baik pusat maupun daerah 
sebagai pihak yang berkepentingan dalam pengadaan tanah untuk kepentingan umum lebih urgen dan memaksa dari pada pihak badan usaha milik negara atau pihak Swasta. Hal ini karena kewajiban pemerintah dalam membanguan insfrastruktur berdasarkan Pasal 33 Undang-Undang Dasar NRI Tahun 1945 (Undang-Undang Dasar 1945, 1945). Dengan demikian, melihat dari urgensi keadaan memaksa dari pihak-pihak yang berkepentingan, perlu ada kajian yang lebih mendalam. Kajian tersebut terkait dengan konsepsi pencabutan hak atas tanah dan konsinyasi yang berakibat hak kepemilikan tanah jatuh pada negara yang diterapkan dalam undang-undang pengadaan tanah untuk kepentingan umum. Sehingga perlu ada rekonstruksi pengertian dari pencabutan hak atas tanah dan konsinyasi dalam undang-undang pengadaan tanah untuk kepentingan umum.

Pengkajian dilakukan dengan pendekatan teori hak asasi manusia, yaitu teori-teori hak asasi manusia, yaitu: hak-hak kodrati (natural rights theory), teori positivisme (positivist theory), dan teori relativisme budaya (cultural relativist theory) (Lubis, 1993). Teori ini digunakan untuk menganalisa Ketidakjelasan definisi kepentingan umum dalam pengadaan tanah yang berakibat dicabutnya hak-hak atas tanah dalam ganti rugi melalui penitipan di pengadilan (konsinyasi). Sedangkan untuk konsep pencabutan hak atas tanah akan dianalisa dengan teori transplantasi hukum (legal transplant theory) (Mistelis, 2000).

Definisi kepentingan umum tersebut dalam undang-undang pengadaan tanah untuk kepentingan umum disebutkan sebagai kepentingan bangsa, negara, dan masyarakat yang diwujudkan oleh pemerintah dan digunakan sebesar-besarnya untuk kemakmuran rakyat (Undang-undang Pengadaan Tanah untuk Kepentingan Umum, 2012). Dalam undang-undang pencabutan hak atas tanah disebutkan bahwa kepentingan umum termasuk kepentingan bangsa dan negara serta kepentingan Bersama dari rakyat, juga kepentingan pembangunan (UU No. 20 Tahun 1961).
Sedangkan dalam Peraturan Presiden Nomor 36 Tahun 2005 tentang Pengadaan Tanah bagi Pelaksanan Pembangunan untuk Kepentingan Umum menyebutkan bahwa kepentingan umum adalah kepentingan Sebagian besar lapisan masyarakat.

Jadi dalam hal ini, yang memiliki hak urgensi dari pencabutan hak atas tanah dan penitipan ganti rugi dan pelepasan hak di pengadilan (konsinyasi) adalah pemerintah, baik pemerintah pusat dan daerah. Sedangkan badan usaha milik negara dan Swasta tidak memiliki urgensi sebagaimana pemerintah. Pihak badan usaha milik negara dan Swasta bersifat membantu pemerintah sebagai alternatif masyarakat untuk menikmati pembangunan insfrastruktur, yaitu setelah kewajiban pemerintah membangun insfrastruktur berikut pengadaan tanahnya telah ada. Sehingga keterlibatan swasta adalah alternatif pilihan berbayar atas infrastruktur tidak berbayar yang dibangun pemerintah. Untuk itu maka penulis melakukan penelitian dalam rangka untuk merekonstruksi pengertian konsep pencabutan hak atas tanah dan konsinyasi ganti rugi di pengadilan dalam undangundang pengadaan tanah untuk kepentingan umum. Rumusan penelitian untuk menjawab masalah ini adalah bagaimana seharusnya definisi pencabutan hak atas tanah dan konsinyasi pada pembangunan infrastruktur publik. Permasalahan utama ini akan dielaborasi dalam lima poin pembahasan dalam penelitian ini.

\section{B. Metode Penelitian}

Penelitian dilakukan secara yuridis normatif dengan pengumpulan data sekunder. Analisa secara kualitatif dengan pendekatan peraturan perundang-undangan dan konsep. Data diperoleh, pertama dari website Badan Pengatur Jalan Tol (BPJT) yang menginformasikan hambatan pembangunan jalan tol adalah salah satunya hambatan pengadaan tanah. Juga website terkait sengketa pertanahan. Kemudian mencari pokok masalah dengan mengumpulkan jurnal-jurnal terkait pencabutan hak atas tanah dan ganti rugi 
dengan penitipan di pengadilan (konsinyasi) serta pengadaan tanah untuk kepentingan umum.

Pokok masalah tersebut kemudian dianalisis dengan peraturan perundangundangan yang berlaku yaitu UndangUndang Nomor 2 Tahun 2012 tentang Pengadaan Tanah untuk Kepentingan Umum, Undang-Undang Nomor 20 tahun 1961 tentang Pencabutan Hak-Hak atas Tanah dan Benda-benda yang berada di atasnya, termasuk UUPA. Disamping itu juga data kasus pengadilan dan buku-buku teks terkait teori dan konsep. Data-data tersebut dianalisa untuk menjawab permasalahan hukum atau temuan hukum dalam penelitian ini, yaitu permasalahan pencabutan hak atas tanah dan konsinyasi ganti rugi di pengadilan dalam undangundang pengadaan tanah untuk kepentingan umum.

\section{Hasil dan Pembahasan}

1. Pencabutan Hak atas Tanah dan Konsinyasi dalam Pengadaan Tanah untuk Kepentingan Umum

Pencabutan hak atas tanah pada umumnya diadakan untuk keperluan usahausaha negara sebagai pemerintah, baik untuk kepentingan pemerintah pusat maupun daerah. Pencabutan hak atas tanah ini mengacu pada Pasal 18 Undang-undang Pokok Agraria (UUPA) hanya dapat dilakukan untuk kepentingan umum (Undang-Undang No. 5 Tahun 1960 Tentang Peraturan Dasar Pokok-Pokok Agraria, 1960). Dalam perkembangannya, ketentuan-ketentuan tersebut tidak menutup kemungkinan sebagai pengecualiannya, dilakukan juga pencabutan hak untuk pelaksanaan usaha-usaha swasta, asal usaha itu benar-benar untuk kepentingan umum dan tidak mungkin diperoleh tanah yang diperlukan melalui persetujuan dengan pemilik tanah. Dalam kasus misalnya pemilik tanah tidak bersedia menyerahkan tanah secara musyawarah, kemudian pemerintah memandang perlu untuk menguasai sebagian tanah masyarakat tersebut, maka keadaan seperti ini, pemerintah menganggap sebagai suatu kepentingan umum. Oleh sebab itu, dapat dilakukan pencabutan hak (Harsono, 2008, p. 445).

Pencabutan hak atas tanah mengacu pada Staatblad 1920 No. 574 yang disebut sebagai "Onteiggenings Ordonantie" yang memberi perlindungan berlebih atas hak kepemilikan perorangan yaitu hak "eigendom", yang bersifat kepemilikan mutlak berdasarkan konsep hukum perdata barat. Dalam memberikan perlindungan tersebut, maka pencabutan hak harus melalui proses yang Panjang dan lama dan harus melalui baik instansi legislative, eksekutif maupun peradilan, namun UUPA tidak lagi didasarkan pada hak mutlak, akan tetapi semua hak atas tanah mempunyai fungsi sosial (Harsono, 2008, p. 444).

Penitipan ganti rugi dan pelepasan hak atas tanah di pengadilan (konsinyasi) berakibat hak kepemilikan tanah mayarakat yang berhak tersebut menjadi hapus dan alat bukti haknya menjadi tidak berlaku serta tanahnya menjadi tanah yang dikuasai negara (Undang-undang Pengadaan Tanah untuk Kepentingan Umum, 2012) pada Pasal 43. Dalam penelitian yang dilakukan oleh Nurazima Faizrosadi dan kawan-kawan dalam kasus pembangunan jalan tol kabupaten Batang, disimpulkan bahwa konsinyasi dalam undang-undang pengadaan tanah untuk kepentingan umum tidak memberikan perlindungan bagi pemilik tanah yang bersengketa dengan pemerintah. Penitipan ganti rugi tanah di pengadilan (konsinyasi) secara hukum tanah dianggap menjadi milik negara. Padahal dalam hukum pertanahan sebagai hukum positif UUPA sudah jelas disebutkan bahwa untuk memperoleh tanah tidak dapat dilakukan dengan paksaan oleh siapapun juga akan tetapi berasaskan kesepakatan, asas keadilan dan asas kemanusiaan (Faizrosadi, Priyono, \& Cahyaningtyas, 2020).

Konsepsi kepentingan umum dalam penjabarannya menunjukkan interpretasi yang lebih luas yang artinya tidak hanya sebatas kepentingan masyarakat umum atau 
kepentingan pemerintah. Kepentingan umum juga masuk kepentingan swasta yang dikemas dalam kegiatan pembangunan ekonomi yang akan memberi manfaat kepada negara dan masyarakat umum. Paradigma yang muncul adalah model kerjasama pemerintah dan swasta, salah satu tipe kontraknya adalah Build Operate Transfer (BOT). Pertimbangan pemerintah dalam model kerjasama pemerintah dan swasta ini adalah keterbatasan dana pemerintah dalam membangun infrastruktur yang memerlukan dana yang cukup tinggi (Joesoef, 2011). Pengertiannya dipengaruhi faktor pertumbuhan dan perkembangan ekonomi yang dicapai masyarakat dan negara. Dengan demikian maka pengertian kepentingan umum bisa juga dikategorikan dalam 2 perspektif yang berbeda.

Pertama pengertian kepentingan umum yang bersifat tradisional: "Traditionally, a public use meant exactly what the words indicated: the land will be for the use of the general public. Under the prevailing eighteenth century doctrine, the public use clause could be read fairly literally: the government could take property for itself, but it was not to take land form 'A' and give to ' $B$ ' ... under the more concervative, historical approach, a public use amounted to land use for all the public." Kedua pengertian kepentingan umum dalam arti modern yang mencakup perluasan makna kegiatan pembangunan: "As the American economy continues to develop, society faces different from of takings than was traditionally experienced through eminent domain. With the evolution of society and the economy, the public use inquiry has also evolved. As the eminent domain power has increasingly been used to take private property in in the name of economic redevelopment, the public use clause has also expanded. In response the federal and state courts have both developed separate ideologies on what is a public purpose in public - private transfer, while at the same time have expanded on each other steps into this area." (Kulick, 2000).

\section{Analisis terhadap Pencabutan Hak atas Tanah dan Konsinyasi dalam Pengadaan Tanah untuk Kepentingan Umum}

Konsep pencabutan hak dan konsep ganti rugi dengan penitipan ganti rugi di pengadilan (konsinyasi) tidak dapat diterapkan secara umum di undang-undang pengadaan tanah untuk kepentingan umum. Pertimbangan pertama adalah, konsep tersebut dalam Undang-undang Nomor 2 Tahun 2012 tentang Pengadaan Tanah Untuk Kepentingan Umum berakibat pada hak kepemilikan tanah mayarakat yang berhak menjadi hapus dan alat bukti haknya menjadi tidak berlaku serta tanahnya menjadi tanah yang dikuasai negara. Hal ini tidak memberikan perlindungan hukum bagi pemilik hak atas tanah. Selain itu juga adanya unsur paksaaan dan tanpa adanya asas kesepakatan, asas keadilan dan asas kemanusiaan sebagaimana yang dilindungi oleh konstitusi undang-undang dasar 1945. Kedua adalah adanya perluasan makna kepentingan umum yang dimaknai untuk kepentingan pemerintah baik pusat maupun daerah, namun juga untuk kepentingan swasta yang membantu pemerintah untuk pembangunan bagi kepentingan umum. Sehingga untuk memberikan keadilan harus dipisahkan untuk kepentingan pemerintah yang memiliki urgensi melaksanakan Pasal 33 UUD 1945 dan kepentingan swasta yang membantu pemerintah yang bersifat alternatif dan tidak urgen.

Ketiga adalah adanya perbedaan urgensi pihak yang memerlukan tanah, dimana pemerintah lebih urgen dan mendesak untuk pengadaan tanah untuk kepentingan umum sebagai kewajiban melaksanakan amanah Pasal 33 UUD 1945. Urgensinya adalah kewajiban membangun infrastruktur publik sebagai amanah konstitusi dengan kondisi keterbatasan dana untuk pengadaan tanah. Sedangkan pihak swasta yang membantu pemerintah dalam membangun infrastruktur bagi kepentingan umum bersifat alternatif pilihan setelah pemerintah membangun infrastruktur bagi kepentingan umum seperti membangun jalan umum dan jembatan 
umum dan infrastruktur lainnya seperti pelabuhan, pengairan, dan lainnya. Sedangkan pihak swasta yang membantu pemerintah seperti membangun jalan tol dan jembatan tol berbayar adalah alternatif bagi masyarakat untuk menggunakannya. Sehingga ada unsur komersial dari pihak swasta yang membantu pemerintah dalam membangun insfratruktur yang membutuhkan tanah. Dengan demikian maka pencabutan hak atas tanah dan pemberian ganti rugi dengan penitipan di pengadilan (konsinyasi) hanya dapat diterapkan apabila pihak yang berkepentingan untuk pengadaan tanah adalah pemerintah, baik pemerintah pusat maupun daerah karena tidak ada unsur komersial.

\section{Pencabutan Hak Atas Tanah dan Konsinyasi vs Hak Asasi Manusia}

Pernyataan Pasal 43 undang-undang pengadaan tanah untuk kepentingan umum (Undang-undang Pengadaan Tanah untuk Kepentingan Umum, 2012), secara eksplisit menyatakan bahwa hak kepemilikan tanah mayarakat yang berhak menjadi hapus dan alat bukti haknya menjadi tidak berlaku serta tanahnya menjadi tanah yang dikuasai negara. Padahal sejarah pembentukan undang-undang pencabutan hak atas tanah dari pemerintahan penjajah Belanda telah memberikan perlindungan bagi pemilikan hak milik atas tanah (hak eigendom). Perlindungan hukum yang diberikan adalah bahwa pencabutan hak atas tanah harus melalui 3 lembaga yaitu lembaga eksekutif, legislative dan yudikatif yang membutuhkan waktu yang panjang (Undang-Undang No. 20 Tahun 1961 tentang Pencabutan Hak Atas Tanah dan Benda-Benda yang Berada di Atasnya, 1961). Konsep tersebut kemudian disesuaikan dengan konsep adanya unsur sosial dalam konsepsi UUPA (Harsono, 2008). Sehingga pencabutan hak atas tanah dan konsinyasi ganti rugi di pengadilan yang berakibat hak kepemilikan tanah jatuh pada negara tanpa kesepakatan dapat melanggar hak asasi manusia, bila tidak dilakukan dengan prosedur melalui 3 lembaga yaitu lembaga eksekutif, legislatif dan yudikatif.

Dalam Pasal 28 H ayat (4) UUD 1945 setelah amandemen I, II, III dan IV disebutkan bahwa: "Setiap orang berhak mempunyai hak milik pribadi dan hak milik tersebut tidak boleh diambil alih secara sewenang-wenang oleh siapapun" (UndangUndang Dasar 1945, 1945). Artinya bahwa konstitusi Indonesia melindungi hak milik pribadi sebagai hak asasi manusia. Dalam penerbitan undang-undang pengadaan tanah untuk kepentingan umum (Undang-undang Pengadaan Tanah untuk Kepentingan Umum, 2012), Tim Advokasi Anti Perampasan Tanah Rakyat mendesak Mahkamah Konstitusi melakukan uji materi terhadap undang-undang tersebut terkait aspek kepentingan umum pengadaan tanah. Tim Advokasi berkesimpulan (Serikat Petani Indonesia, 2012) diakses tanggal 24 Februari 2014:

1. Undang-Undang No. 2 Tahun 2012 tidak sinkron antara judul dengan isi batang tubuh undang-Undang a quo sehingga bertentangan dengan Pasal 1 (3) UUD 1945.

2. Undang-Undang No. 2 Tahun 2012 saling bertentangan yang berakibat ketidakpastian hukum dan bertentangan dengan Pasal 28D (1) UUD 1945.

3. Undang-Undang No. 2 Tahun 2012 tidak dipergunakan sebesar-besarnya untuk kemakmuran rakyat sehingga bertentangan dengan Pasal 33 (3) UUD 1945.

4. Undang-Undang No. 2 Tahun 2012 tidak menjamin perlindungan dan penghormatan hak asasi manusia sehingga bertentangan denagn Pasal 28A, Pasal 28G (1), Pasal 28H (1) dan (4) UUD 1945.

5. Undang-Undang No. 2 Tahun 2012 tidak menjamin persamaan dihadapan hukum sehingga bertentangan dengan Pasal 27 (1) UUD 1945.

6. Undang-Undang No. 2 Tahun 2012 sangat jelas berpotensi merugikan hakhak konstitusional para pemohon 
judicial review atas undang-undang tersebut.

7. Sehingga Tim Advokasi meminta Pasal 2 huruf (g), Pasal 9 ayat (1), Pasal 10, Pasal 14, Pasal 21 ayat (1), Pasal 23 ayat (1), Pasal 40 dan 42 Undang-Undang No. 2 Tahun 2012 untuk dinyatakan tidak mempunyai kekuatan hukum mengikat karena bertentangan dengan Pasal 1 (3), Pasal 28D (1), Pasal 28A, Pasal 33 ayat (3), Pasal 28G (1),Pasal 28H (4), Pasal 27 (1) dan Pasal 2H (1) UUD 1945.

Jadi dapat dilihat bahwa pembuatan undangundang pengadaan tanah untuk kepentingan umum banyak yang tidak sesuai dengan ketentuan-ketentuan konstitusi UUD 1945 yang dalam harmonisasi peraturan perundang-undangan tidak sinkron secara vertikal.

Mengacu pada konteks hak asasi manusia terkait pengadaan tanah untuk kepentingan umum, ada beberapa teori yang biasanya digunakan yaitu teori-teori hak asasi manusia, yaitu: hak-hak kodrati (natural rights theory), teori positivism (positivist theory), dan teori relativisme budaya (cultural relativist theory). Teori hak-hak kodrati menyatakan bahwa hak asasi manusia adalah hak-hak yang dimiliki oleh semua orang, setiap saat, dan di semua tempat karena pada prinsipnya setiap manusia dilahirkan sebagai manusia. Teori positivisme secara tegas menolak pandangan teori hak-hak kodrati, sedangkan teori relativisme budaya memandang teori hakhak kodrati dan penekanannya pada universalitas sebagai suatu pemaksaan atas budaya terhadap budaya yang lain (Lubis, 1993, pp. 15-16). Terlepas dari teori-teori tersebut, dalam pengadaan tanah untuk kepentingan umum harus ada kesepakatan bilateral antara semua anggota masyarakat. Kesepakatan tersebut harus berdasarkan prinsip hak milik pribadi yang merupakan suatu klaim moral (Shapiro, 2006, p. 289).

Ketidakjelasan definisi kepentingan umum dalam pengadaan tanah yang berakibat dicabutnya hak-hak atas tanah dalam ganti rugi melalui penitipan di pengadilan (konsinyasi) jelas akan melanggar hak asasi manusia. Para anggota dewan (legislator) tidak bisa membiarkan ketidakjelasan substansi undang-undang dan menyerahkannya kepada hakim pengadilan. Seperti istilah "good faith", "due care" atau juga "kepentingan umum" dan menyerahkan interpretasi istilah tersebut kepada hakim pengadilan. Istilah-istilah yang tidak jelas tersebut dalam pelaksanaannya akan memberikan kesalahan interpretasi. Ketidakjelasan tersebut akan menimbulkan permasalahan hukum terkait masalah substansi moral undang-undang (Fuller, 1964, pp. 63-91).

Dalam penerapan konsep pencabutan hak dan ganti rugi dengan penitipan di pengadilan (konsinyasi) terdapat 2 pendapat yang bertentangan. Pendapat pertama dari Alan Watson yang menyatakan transplantasi suatu konsep dalam suatu perundangundangan dapat dilakukan dengan mudah (Teori Power - Legal Transplant Theory). Namun untuk masalah pengadaan tanah untuk kepentingan umum ini lebih tepat apa yang dikatakan oleh Kahn-Freund, yang menyatakan tidak setuju dengan asumsi Watson. Kahn-Freund menyatakan bahwa hukum tidak harus dipisahkan dari tujuannya atau dari keadaan-keadaan dimana hukum itu dibuat.

Pertimbangan dari Kahn_Freund tersebut di atas adalah kita tida $\bar{k}$ dapat menjamin norma-norma atau lembagalembaga itu dapat ditransplantasikan dalam undang-undang. Dalam hal tersebut terdapat tingkat-tingkat dalam pemindahan normanorma atau lembaga-lembaga tersebut (Mistelis, 2000). Pendapat Kahn_Freund tersebut sangat dipengaruhi oleh pemikiran Carl Von Savigny, dari mazhab hukum sejarah Jerman. Von Savigny menyatakan bahwa hukum positif adalah berasal dari spirit masyarakatnya (volkgeist). Pendapat ini lebih tepat terkait masalah-masalah hukum yang terkait Pasal 33 UUD 1945 (Chand, 1994, p. 125). Khususnya terkait dengan tanah di Indonesia bersumber dari hukum adat, yang masih diakui oleh konstitusi dan hukum positif pertanahan 
UUPA sepanjang masih ada. Dengan demikian masyarakat Indonesia sudah memiliki norma-norma hukum pertanahan. Kecuali norma-norma yang belum ada seperti yang terkait pasar modal, hak atas kekayaan intelektual, investasi, maka pemerintah dapat mengambil norma-norma luar untuk di transplantasikan dalam peraturan perundang-undangan berdasarkan teori Power dari Alan Watson (Mistelis, 2000).

\section{Perluasan Makna Kepentingan Umum: Pemerintah vs Swasta}

Pencabutan hak atas tanah dan kepentingan umum sangat jelas hubungannya dimana pencabutan hak atas tanah hanya diperkenankan karena alasan kepentingan umum disertai dengan ganti rugi yang layak (Safik, 2006). Dalam hal tidak adanya klausula kepentingan umum, maka pencabutan hak atas tanah atau apapun kegiatan yang dianggap sebagai pencabutan hak atas tanah tidak dapat dibenarkan. Demikian juga secara analogi atas ganti rugi dengan penitipan di pengadilan (konsinyasi) yang menghilangkan kekuatan bukti hak atas tanah dan tanah menjadi tanah negara dalam undang-undang pengadaan tanah untuk kepentingan umum. Kedua konsep tersebut perlu pengkajian mendalam dalam penerapannya dalam undang-undang pengadaan tanah untuk kepentingan umum. Pertimbangannya adalah bahwa telah terjadi perluasan makna kepentingan umum akibat perkembangan paradigma kerjasama pemerintah dan swasta dalam membangun infrastruktur publik. Dalam perkembangannya infrastruktur publik dapat bersifat non komersialdan bersifat komersial. Sehingga ini perlu kajian untuk memberikan rasa keadilan bagi masyarakat pemilik tanah yang digunakan untuk kepentingan umum.

Dalam penelitian Akhmad Safik, mengutip kasus Arief Wirasana cs melawan Gubernur Kepala Daerah Khusus Ibukota Jakarta No. 627/1969 G mengenai sengketa kompleks "Yenpin" dimana pengadilan Jakarta memeriksa gugatan terhadap SK
Gubernur DKI Jakarta No. 11/9/25/1969 yang menurut penggugat tidak memenuhi syarat. Menurut penggugat pencabutan hak atas tanah hanya dapat dilakukan dalam keadaan yang memaksa atau untuk kepentingan umum. Kewenangannya hanya dimiliki oleh Presiden sebagaimana undangundang pencabutan Hak atas Tanah Nomor 20 Tahun 1961. Dalam sejarah pencabutan hak atas tanah, hanya terjadi atas pencabutan hak atas tanah kasus kompleks "Yenpin" berdasarkan undang-undang pencabutan hak atas tanah yang dikenal secara wajib bukan sukarela (Undang-Undang No. 20 Tahun 1961 tentang Pencabutan Hak Atas Tanah dan Benda-Benda yang Berada di Atasnya, 1961) berdasarkan Keputusan Presiden. Sedangkan untuk pencabutan hak atas tanah "Proyek Senen", "Proyek Universitas Indonesia di Situ Gintung", Keputusan Presiden mengenai pencabutan hak atas tanah hingga sekarang belum ada (Tukgali, 2010, pp. 405-406).

Dalam penelitian sebelumnya (Joesoef, 2011), pada Subdit Pengadaan Tanah Departemen Pekerjaan Umum tanggal 3 Mei 2010, untuk pencabutan hak atas tanah tidak didapatkan data tersebut. Hasil wawancara dijelaskan bahwa pencabutan hak atas tanah sulit dilakukan pemerintah dengan alasan zaman era reformasi. Kebanyakan sengketa tanah diselesaikan dengan cara konsinyasi di pengadilan. Sejak undang-undang tentang jalan disahkan (Undang-Undang Nomor 38 Tahun 2004 Tentang Jalan, 2004), konfirmasi dari wawancara di Subdit Pengadaan Tanah kementerian Pekerjaan umum tersebut, pemerintah belum pernah melakukan pencabutan hak atas tanah. Alasan pemerintah adalah selain alasan era reformasi juga ada alasan bahwa masyarakat dapat menggugat balik pemerintah. Namun dalam kenyataannya pemerintah menggunakan konsep ganti rugi dengan penitipan di pengadilan. Akibat hukumnya adalah bahwa hak kepemilikan tanah mayarakat yang berhak tersebut menjadi hapus dan alat bukti haknya menjadi tidak berlaku serta tanahnya menjadi tanah yang dikuasai negara. 
Dengan diundangkannya undangundang tentang jalan, maka secara parsial undang-undang pengadaan tanah untuk kepentingan umum telah sinkron dengan regulasi hukum infrastruktur, khususnya infrastruktur jalan tol yang membutuhkan tanah. Landasan hukum infrastruktur jalan tol dalam undang-undang jalan (UndangUndang Nomor 38 Tahun 2004 Tentang Jalan, 2004), menetapkan bahwa kepemilikan tanah secara hukum ada pada pemerintah, walaupun dibiayai oleh investor swasta dalam model kerjasama pemerintah dan swasta (Joesoef, 2011). Tanah yang sudah dibebaskan dan dikuasai pemerintah dalam rangka pembangunan jalan tol didaftarkan untuk diterbitkan sertipikat atas nama pemerintah. Kepemilikan tanah yang dibebaskan ini juga telah ditegaskan dalam Pasal 12 Undang-undang Pengadaan Tanah untuk Kepentingan Umum, yang merupakan perintah dan kewajiban disertai sanksi (Tebbit, 2000). Namun sinkronisasi regulasi infrastruktur jalan tol dan regulasi pengadaan tanah untuk kepentingan umum ini justru memberikan ketidakadilan bagi masyarakat pemilik hak atas tanah. Sehingga perlu pengkajian secara mendalam terkait dengan konsep hak asasi manusia dan konstitusi UUD NRI Tahun 1945.

Pengertian kepentingan umum tersebut dalam pelaksanaannya menunjukkan adanya suatu interpretasi yang lebih luas. Dalam penjabarannya adalah karena kepentingan umum tidak hanya diartikan hanya sebatas kepentingan umum atau khusus kepentingan umum pemerintah baik pusat maupun daerah. Kepentingan umum tersebut juga untuk kepentingan swasta yang dikemas dalam kegiatan pembangunan ekonomi yang akan memberikan manfaat kepada negara dan masyarakat umum. Dengan demikian pengertian kepentingan umum megalami perubahan dan perkembangan lebih lanjut sejalan dengan perkembangan kemajuan masyarakat. Jadi, pengertian kepentingan umum memiliki 2 perspektif yang berbeda yaitu perspektif tradisional dan perspektif modern (Kulick, 2000).

\section{Pengadaan Kepentingan Komersialisasi Tanah untuk
Umum dan
Pembangunan Infrastruktur}

Pengadaan tanah untuk kepentingan umum dalam konteks komersialisasi pembangunan infrastruktur dapat dilihat dari fenomena bahwa infrastruktur jalan tol bersifat komersial atau mencari keuntungan. Dalam kajian secara konsep dan teori, suatu pembangunan infrastruktur publik yang bersifat komersial seperti jalan tol (jalan berbayar) walupun dilakukan dan dimiliki oleh negara dalam model kejasama pemerintah swasta, tidak dapat dikategorikan sebagai kepentingan umum. Dasarnya adalah ketidakadilan. Konsepsi kerjasama pemerintah swasta sebagai suatu paradigma baru untuk membangun infrastruktur, memerlukan badan hukum publik yang lebih efisien dan keterlibatan pihak swasta yang lebih besar dalam jasa pelayanan infrastruktur. Hal ini sudah masuk dalam gelombang swastanisasi infrastruktur global dan liberalisasi yang mulai pada tahun 1990-an (Kamerman \& Kahn, 1989). Paradigma baru konsepsi kerjasama pemerintah swasta ini penting dikaji lebih jauh untuk mengklasifikasikan barang dan jasa mana atau infrstruktur mana yang bisa di swastanisasikan (privatisasi) dan mana yang merupakan sektor publik.

Dari pendekatan tersebut diatas, jalan tol berdasarkan undang-undang jalan (Undang-Undang Nomor 38 Tahun 2004 Tentang Jalan, 2004), merupakan barang dan jasa umum (common-pool goods) yang bergeser kearah barang dan jasa komersial (toll goods) (Dhiratayakinant, 1989). Konstitusi UUD NRI Tahun 1945 memang tidak mengenal klasifikasi barang dan jasa seperti ini, maka secara substansial jalan tol termasuk kategori "toll goods" yang tidak dikenal dalam UUD NRI Tahun 1945. Dalam hal ini, pertimbangannya adalah bahwa jalan tol merupakan barang dan jasa umum yang pemakaiannya secara bersamasama dan dibedakan dari barang dan jasa swasta yang pemakaiannya dilakukan secara individu. Namun dalam pelaksanaan 
undang-undang pengadaan tanah untuk kepentingan umum, kedua klasifikasi tersebut tidak dibedakan. Hal ini tentu tidak memberikan keadilan masyarakat pemilik hak atas tanah yang digunakan untuk membangun infrastruktur publik.

Dilihat dari sejarah regulasi infrastruktur jalan tol tahun 2004, awalnya pemerintah masih mengacu pada Pasal 33 UUD NRI Tahun 1945, namun dengan regulasi infrastruktur jalan tol, pemerintah kemudian menetapkan bahwa biaya pengadaan tanah dapat menggunakan dana yang berasal dari pemerintah dan/atau badan usaha (Undang-Undang Nomor 38 Tahun 2004 Tentang Jalan, 2004) pada Penjelasan butir 1 Umum. Dalam implementasinya biaya pengadaan tanah tersebut merupakaan biaya investasi bagi investor swasta jalan tol (Laporan BPJT (22 Februari 2010), Pengembangan Jalan Tol Di Indonesia, 2010). Kemudian biaya tersebut menjadi bagian dari modal (equity) bagi badan usaha jalan tol ("Perjanjian Pengusahaan Jalan Tol Ruas Depok - Antasari Nomor: 191/PPJT/V/Mn/2006 Tanggal 29 Mei 2006 antara PT Citra Waspphutowa dan Pemerintah cq Departemen Pekerjaan Umum," 2006).

\section{Simpulan dan Saran}

Pencabutan hak atas tanah secara eksplisit tidak disebutkan dalam undangundang pengadaan tanah untuk kepentingan umum. Namun konsep konsinyasi yaitu penitipan ganti rugi di pengadilan memiliki makna yang sama. Hal ini karena prosedur ganti rugi dengan penitipan di pengadilan (konsinyasi) berakibat hukum bahwa hak kepemilikan tanah mayarakat yang berhak tersebut menjadi hapus dan alat bukti haknya menjadi tidak berlaku serta tanahnya menjadi tanah yang dikuasai negara. Hal ini memberikan ketidakadilan bagi masyarakat karena pada awalnya pengadaan tanah untuk kepntingan umum dilakukan oleh pihak yang membutuhkan tanah adalah pemerintah baik pusat maupun daerah. Hal ini seseuai dengan amanah Pasal 33 (3) UUD NRI Tahun 1945 adalah kewajiban pemerintah membangun infrastruktur publik. Dalam perkembangan regulasi jalan tol, kemudian pemerintah memperluas makna kepentingan umum yang tidak hanya untuk kepentingan pemerintah namun juga untuk kepentingan swasta yang membantu pemerintah dalam konsep kerjasama pemerintah swasta, yang konsepsinya bersifat komersial.

Dalam hal ini perlu ada pemisahan penggunaan konsep pencabutan hak atas tanah dan konsinyasi dalam undang-undang pengadaan tanah untuk kepentingan umum. Pemisahan tersebut terkait dengan urgensi pemerintah adalah melaksanakan amanah Pasal 33 (3) UUD NRI Tahun 1945 untuk membangun infrastruktur publik tidak berbayar. Sedangkan urgensi swasta dalam pola kerjasama pemerintah bersifat alternatif atau pilihan bagi masyarakat setelah pemerintah membangun infrastruktur publik tidak berbayar. Sebagai contoh, jalan tol yang dibangun swasta dalam model kerjasama pemerintah swasta dilakukan setelah pemerintah membangun jalan umum tidak berbayar. Dengan demikian berdasarkan analisa teori hak asasi manusia dan teori transplantasi hukum dari KahnFreund bahwa hukum positif adalah berasal dari spirit masyarakatnya (volkgeist). Dengan demikian konsepsi pencabutan hak atas tanah dan konsinyasi dalam pengadaan tanah untuk kepentingan umum dapat diterapkan pada pihak yang berkepentingannya adalah pemerintah, baik pusat maupun daerah. Sedangkan bagi pihak swasta dalam model kerjasama pemerintah swasta tidak dapat dikenakan karena bersifat komersial.

Kekurangan penelitian ini adalah belum banyak mendapatkan data kasus-kasus ganti rugi dengan penitipan di pengadilan. Dalam hal ini, baik atas data proyek-proyek pembangunan infrastruktur publik yang dilaksanakan oleh pemerintah pusat atau daerah, maupun atas proyek-proyek pembangunan instruktur publik dalam model kerjasama pemerintah swasta. Sehingga dalam penelitian ini belum didapat pertimbangan-pertimbangan hakim pengadilan dalam memutus sengketa hak 
atas tanah dalam prosedur konsinyasi. Sebagai penelitian yang masih ada kekurangan ini, semoga bisa menjadi sumber awal penelitian lebih lanjut atas konsepsi pencabutan hak atas tanah dan konsinyasi dalam undang-undang pengadaan tanah untuk kepentingan umum. Sehingga dapat memberikan rasa keadilan bagi masyarakat.

\section{DAFTAR PUSTAKA}

Ade, A. F. (2018). Pergeseran Pola Perlindungan Hukum dalam Pengadaan Tanah Untuk Kepentingan Umum. Yogyakarta: Graha Ilmu.

Chand, H. (1994). Modern Jurisprudence (1994). Kuala Lumpur: International Law book Services.

Dhiratayakinant, K. (1989). Privatization: an analysis of the concept and its implementation in Thailand. Bangkok, Thailand: Thailand Development Research Institute.

Faizrosadi, N., Priyono, P., \& Cahyaningtyas, I. (2020). Penitipan Ganti Rugi Pemegang Hak dalam Pengadaan Tanah Pembangunan Jalan Tol Batang. NOTARIUS, 13(2), 605618.

Fuller, L. L. (1964). The morality of law. New Haven and London: Yale University Press.

Harsono, B. (2008). Hukum Agraria Indonesia, Himpunan PeraturanPeraturan Hukum Tanah. Jakarta: Penerbit Djambatan.

Joesoef, I. E. (2011). Model kerjasama pemerintah dan swasta: studi penerapan kontrak build operate transfer dalam perjanjian pengusahaan jalan tol di Indonesia. Universitas Indonesia.

Kamerman, S. B., \& Kahn, A. J. (1989). Privatization and the welfare state. Princeton University Press.
Kasenda, D. G. G. (2017). Ganti Rugi Dalam Pengadaan Tanah Untuk Kepentingan Umum. MORALITY: Jurnal Ilmu Hukum, 2(2), 122-141.

Kulick, P. J. (2000). Rolling the Dice: Determining Public Use in Order to Effectuate a Public-Private Taking-A Proposal to Redefine Public Use. $L$. Rev. MSU-DCL, 639.

Laporan BPJT (22 Februari 2010), Pengembangan Jalan Tol Di Indonesia. (2010).

Lubis, T. M. (1993). In search of human rights: legal-political dilemmas of Indonesia's New Order, 1966-1990. PT Gramedia Pustaka Utama.

Mistelis, L. A. (2000). Regulatory aspects: Globalization, harmonization, legal transplants, and law reform-Some fundamental observations. The International Lawyer, 1055-1069.

Perjanjian Pengusahaan Jalan Tol Ruas Depok - Antasari Nomor: 191/PPJT/V/Mn/2006 Tanggal $29 \mathrm{Mei}$ 2006 antara PT Citra Waspphutowa dan Pemerintah cq Departemen Pekerjaan Umum. (2006).

Pratama, M. Y. (2019). Pencabutan Hak Atas Kepemilikan Tanah dan BendaBenda yang Ada di Atasnya. LEX PRIVATUM, 6(9).

Safik, A. (2006). Tanah untuk kepentingan umum. Fakultas Hukum Universitas Indonesia, Lembaga Studi Hukum dan Ekonomi.

Serikat Petani Indonesia. (2012). Judicial Review UU No. 2 Tahun 2012 tentang Pengadaan Tanah bagi Pembangunan untuk Kepentingan Umum. Retrieved from http://www.spi.or.id/?p=4966

Shapiro, I. (2006). Evolusi Hak dalam Teori Liberal. Jakarta: Yayasan Obor Indonesia.

Tebbit, M. (2000). Philosophy of Law: An 
Introduction. London and New York: Routledge.

Toll Road Regulator (Badan Pengatur Jalan Tol). (n.d.). Jalan Tol Beroperasi. Retrieved August 10, 2015, from http://bpjt.pu.go.id/konten/progress/bero perasi

Tukgali, L. L. (2010). Fungsi sosial hak atas tanah dalam pengadaan tanah untuk kepentingan umum = Social functions on land rights in respect to land procurement for public interest purposes. Universitas Indonesia.

Undang-Undang Dasar 1945 Indonesia.
Undang-Undang No. 20 Tahun 1961 tentang Pencabutan Hak Atas Tanah dan BendaBenda yang Berada di Atasnya, Pub. L. No. No. 20 Tahun 1961 (1961). Indonesia.

Undang-Undang No. 5 Tahun 1960 Tentang Peraturan Dasar Pokok-Pokok Agraria, Pub. L. No. No. 5 Tahun 1960 Tentang Peraturan Dasar Pokok-Pokok Agraria (1960). Indonesia.

Undang-Undang Nomor 38 Tahun 2004 Tentang Jalan (2004).

Undang-undang Pengadaan Tanah untuk Kepentingan Umum, Pub. L. No. 2 Tahun 2012 (2012). Indonesia. 